\title{
К ВОПРОСУ О БЕЗОПАСНОСТИ СЫРЬЯ И ПРОДУКТОВ ПЕРЕРАБОТКИ ИЗ ОЛЕНИНЫ
}

\begin{abstract}
А. Т. Инербаева
В статье дана оценка качества и безопасности оленины и продукта переработки - сыровяленого колбасного изделия суджук «Праздничный». Мясо северных оленей является не только высокобелковым сырьем, оно содержит водорастворимые витамины, имеет структурные и технологические особенности. Сырьё прошло ветеринарно-санитарную экспертизу в органах государственной ветеринарной службы и сопровождалось соответствующей формой ветеринарного сопроводительного документа (форма № 2). Микробиологическая безопасность оленины, выращенной в условиях Крайнего Севера, показала соответствие сырья животного происхождения гигиеническим нормам. По упитанности молодняк оленей отнесен к первой категории. По органолептическим показателям оленина поступила свежая, без постороннего запаха. Приведена краткая технология получения сыровяленого продукта из оленины: подготовка сырья - размораживание, обвалка, жиловка; нарезание оленины на куски, шпика хребтового - на полосы, подмораживание сырья; приготовление фарша; подготовка пряностей, чеснока, подготовка оболочки, наполнение оболочки фраршем, осадка; обработка дымом; сушка суджука, охлаждение; контроль качества; упаковка, маркировка, транспортирование, хранение. Проведенная оценка безопасности продукта переработки - сыровяленого колбасного изделия суджук «Праздничный» - по микробиологическим и другим исследованиям показала соответствие существующим нормативным требованиям.

Ключевые слова: оленина, безопасность, качество, микробиологические показатели, технология, сыровяленые колбасные изделия, суджук.
\end{abstract}

\section{ВВЕДЕНИЕ}

Производство продуктов здорового питания на основе местного и регионального сырья является актуальной проблемой в создании устойчивой продовольственной базы Российской Федерации. Государственную политику в области здорового питания и обеспечения качества и безопасности сырья и продуктов питания определяют программные документы: подписанное председателем Правительства РФ распоряжение № 1364-р от 29 июня 2016 г. «Об утверждении стратегии повышения качества пищевой продукции в Российской Федерации до 2030 года» и Указ Президента РФ от 13 мая 2017 г. № 208 «О Стратегии экономической безопасности Российской Федерации на период до 2030 года» $[1,2]$.

Источниками полноценного белка, содержащего полный набор незаменимых аминокислот в количестве, достаточном для биосинтеза белка в организме человека, являются продукты животного происхождения, белки которых усваиваются организмом на 93-96 \%, исходя из норм физиологических потребностей в энергии и пищевых веществах для различных групп населения Российской Федерации (MP 2.3.1.2432-08) [3].

Современной стратегией производства продуктов питания является изыскание новых ресурсов незаменимых компонентов пищи (белка, витаминов и др.), использование нетрадиционных видов сырья, создание новых прогрессивных технологий, позволяющих повысить пищевую и биологическую ценность продукта, придать ему заданные свойства, значительно увеличить срок хранения и т. д [4].

Высокобелковым продуктом питания $(20,4-23,16 \%)$, не уступающим по содержанию белка говядине $(20,12-21,40 \%)$ и свинине (19,5-21,3\%), является оленина [5]. Мясо северного оленя является не только ценнейшим источником белка, но и витаминов, причем в мышечной ткани преобладают водорастворимые витамины. Количество жирорастворимых витаминов в мясе увеличивается с повышением упитанности животных [6]. По сравнению с говядиной и бараниной оленина отличается большей нежностью: в туше северного оленя слабее развиты прослойки соединительной ткани, мускульное волокно отличается несколько меньшей толщиной, выше содержание влаги и ниже содержание жира. Цвет мяса оленей темнее говядины, 


\section{А. Т. ИНЕРБАЕВА}

что связано с повышенным содержанием гемоглобина, на разрезе мелкозернистое, без мраморности (без прослоек жира), мышечные волокна тонкие, нежные и соединены в небольшие мышечные пучки, консистенция от плотной до упругой, запах слабо специфический [7].

Цель работы - оценка безопасности оленины и продукта переработки из нее.

\section{ЭКСПЕРИМЕНТАЛЬНАЯ ЧАСТЬ}

Объектом исследования являлись оленина, а также продукт переработки из нее сыровяленое колбасное изделие суджук «Праздничный». Всё мясное сырьё, полученное нами от поставщика, соответствовало требованиям правил санитарного осмотра убойных животных и ветеринарно-санитарной экспертизы мяса и мясных продуктов (ветеринарное свидетельство фрормы 2). Экспериментальные, микробиологические, аналитические исследования проводились согласно требованиям ГОСТ Р 55499-2013 в государственном научном учреждении «Сибирский научно-исследовательский институт переработки сельскохозяйственной продукции» (р.п. Краснообск, Новосибирская область) в лабораториях технологий мяса и мясных продуктов; микробиологические испытания проведены в лаборатории микробиологических исследований СибНИИП (исследования проводили по ГОСТ 26668, ГОСТ 26669, ГОСТ 29185, ГОСТ 10444.2, ГОСТ 10444.15, ГОСТ 30518, ГОСТ 30519, ГОСТ 30726, МУК 4.2.1122). Физико-химические показатели (определение влаги - по ГОСТ 9793; определение жира - по ГОСТ 23042; определение белка - по ГОСТ 25011), безопасность сырья и готовых сырокопченых колбасных изделий исследованы в Облветлаборатории и ЦСМ г. Новосибирска (определение содержания нитритов - по ГОСТ 8558.1, содержание токсичных элементов по ГОСТ 26927, ГОСТ 26929, ГОСТ 26930, ГОСТ 26932, ГОСТ 26933, ГОСТ Р 51301, определение пестицидов - по МУ 1222, МУ 2142, определение антибиотиков - по МУ 3049, МУК 4.2.026, определение нитрозаминов - по МУК 4.4.1.011, МУ 2482, определение радионуклидов - по МУК 2.6.1.1194, определение бенз(а)пирена по ГОСТ Р 51650.

\section{РЕЗУЛЬТАТЫ И ОБСУЖДЕНИЕ}

Мясо северного оленя нами оценивалось по РСТ РСФСР 402-90 (в настоящее время ГОСТ 32227-2013) [8]. Молодняк оле- ней в зависимости от упитанности отнесен к первой категории, соответствие требованиям указано в таблице 1.

Таблица 1 - Упитанность молодняка оленей

\begin{tabular}{|l|l|}
\hline $\begin{array}{c}\text { Катего- } \\
\text { рия }\end{array}$ & \multicolumn{1}{|c|}{ Требования } \\
\hline Первая & $\begin{array}{l}\text { Формы туловища округлые, муску- } \\
\text { латура развита хорошо; седалищ- } \\
\text { ные бугры и маклоки слегка замет- } \\
\text { ны; остистые отростки спиных и } \\
\text { поясничных позвонков не выступа- } \\
\text { ют. Подкожные жировые отложения } \\
\text { прощупываются у основания хво- } \\
\text { ста }\end{array}$ \\
\hline Вторая & $\begin{array}{l}\text { Формы туловища угловатые, му- } \\
\text { скулатура развита удовлетвори- } \\
\text { тельно; на бедрах заметны впади- } \\
\text { ны; седалищные бугры и маклоки } \\
\text { выступают отчетливо; остистые } \\
\text { отростки спинных и поясничных } \\
\text { позвонков выступают незначитель- } \\
\text { но. Подкожные жировые отложения } \\
\text { у основания хвоста незначитель- } \\
\text { ные или отсутствуют }\end{array}$ \\
\hline
\end{tabular}

По органолептическим показателям оленина поступила свежая, без постороннего запаха. Мясо прибыло в замороженном виде. Разделку проводили согласно схеме разделки по ГОСТ 32243-2013 [9].

Мышечная ткань северного оленя была красного цвета, имела мелкую зернистость и тонкую волокнистость, однородную на поперечном разрезе, мраморность отсутствовала, прослойки соединительной ткани в ней были незначительны и состояли в основном из рыхлой соединительной ткани. На разрезе мясо «эластичное», блестящее, умеренно влажное, жир слабо-розового цвета твердой консистенции.

Микрофрлора пищевых продуктов обусловливает определённые сроки их хранения, качество, органолептические свойства, тормозит размножение в них патогенной микрофрлоры [10]. По микробиологическим показателям МАФАнМ, БГКП, Salmonella, Listeria monozitogenes оленина соответствовала гигиеническим нормам.

Остальное соответствие по требуемым гигиеническим нормам по показателям безопасности мяса оленей представлены в таблице 2. 
Таблица 2 - Показатели безопасности мяса оленей

\begin{tabular}{|c|c|c|}
\hline Показатель & $\begin{array}{c}\text { Допустимые } \\
\text { нормы по НД } \\
\text { мг/кг, не более }\end{array}$ & $\begin{array}{l}\text { Результаты } \\
\text { испытаний }\end{array}$ \\
\hline Кадмий & 0,05 & менее 0,03 \\
\hline Свинец & 0,5 & 0,022 \\
\hline Мышьяк & 0,1 & менее 0,05 \\
\hline Ртуть & 0,03 & $\begin{array}{l}\text { менее } \\
0,0015\end{array}$ \\
\hline $\begin{array}{l}\text { Антибиотики: } \\
\text { Левомицетин } \\
\text { Тетрациклин. } \\
\text { группа } \\
\text { Гризин } \\
\text { Бацитрацин }\end{array}$ & $\begin{array}{l}\text { Не доп. } \\
\text { Не доп. } \\
\text { Не доп. } \\
\text { Не доп. }\end{array}$ & $\begin{array}{c}\text { He } \\
\text { обнару- } \\
\text { жены }\end{array}$ \\
\hline $\begin{array}{l}\text { ГХЦГ } \\
\text { (альфа, бета, } \\
\text { гамма изоме- } \\
\text { ры) }\end{array}$ & 0,1 & $\begin{array}{c}\text { Не обнару- } \\
\text { жены }\end{array}$ \\
\hline $\begin{array}{l}\text { ДДТ и его ме- } \\
\text { таболиты }\end{array}$ & 0,1 & $\begin{array}{c}\text { He обнару- } \\
\text { жены }\end{array}$ \\
\hline $\begin{array}{l}\text { Радионуклиды: } \\
\text { Цезий - } 137 \\
\text { Стронций - } 90\end{array}$ & $\begin{array}{l}180 \text { БК/Кг } \\
80 \text { БК/Кг }\end{array}$ & $\begin{array}{l}1,20 \text { Бк/кг } \\
3,10 \text { Бк/кг }\end{array}$ \\
\hline
\end{tabular}

Примечание: ГХЦГ - гексахлорциклогексан, ДДТ диметилдинитротолуол

При приемке сырье осматривали и при необходимости подвергали дополнительной зачистке и промывке. Размораживание проводили при температуре $8-10^{\circ} \mathrm{C}$ в течение 20-24 часов до тех пор, пока температура в толще туш будет не ниже $1^{\circ} \mathrm{C}$.

На обвалку направили размороженное сырье с температурой не ниже $1^{\circ} \mathrm{C}$. При жиловке мяса удаляли пленки, сухожилия, хрящи, лимфатические узлы, кровоподтеки, выделяли первый сорт. Жилованная односортная оленина содержала соединительной ткани не более $20 \%$. В процессе жиловки мясо разрезали на куски массой от 100 до 500 г, шпик свиной хребтовый и боковой - на полосы размером примерно 15×30 см. Перед измельчением жир-сырец, шпик охлаждали до температуры $0 . . .-1^{\circ} \mathrm{C}$.

В данной работе нами рассмотрена технологическая схема производства суджука сыровяленого, которая состоит из следующих стадий производства: подготовка сырья размораживание, обвалка, жиловка; нарезание оленины на куски массой 250 г, шпика хребтового - на полосы размером 15-30 см, подмораживание сырья до температуры 3-5 ${ }^{\circ} \mathrm{C}$; приготовление фарша в соответствии с рецептурой (65\% - на куттере, $10 \%$ - на волчке), температура готового фарша $1-4{ }^{\circ} \mathrm{C}$; подготовка пряностей, чеснока, подготовка оболочки, наполнение оболочки фраршем, осадка 3 суток; обработка дымом при температуре $22-24^{\circ} \mathrm{C}$ в течение 2-3 суток; сушка суджука - 3-5 суток при температуре $12-13^{\circ} \mathrm{C}$, влажности воздуха $80-85 \%$, окончательная - 10-12 ${ }^{\circ} \mathrm{C}$, влажность воздуха $75-78 \%$; охлаждение $\left(8{ }^{\circ} \mathrm{C}\right)$; контроль качества; упаковка, маркировка, транспортирование, хранение.

Микробиологические показатели безопасности продуктов переработки из оленины исследованы в лаборатории микробиологических исследований СибНИИП. По показателям МАФАнМ, БГКП, Salmonella, Listeria monozitogenes, S/ aureus, сульфритредуцирующие клостридии сыровяленый суджук «Праздничный» соответствовал гигиеническим нормам.

Другие показатели безопасности готовых сыровяленых колбасных изделий, исследованные в Облветлаборатории и ЦСМ г. Новосибирска, представлены в таблице 3.

Таблица 3 - Показатели безопасности суджука «Праздничный»

\begin{tabular}{|c|c|c|}
\hline Показатель & $\begin{array}{c}\text { Допустимые } \\
\text { уровни, } \\
\text { не более }\end{array}$ & $\begin{array}{c}\text { суджук } \\
\text { «Праздничный» }\end{array}$ \\
\hline $\begin{array}{l}\text { Свинец } \\
\text { Мышьяк } \\
\text { Кадмий } \\
\text { Ртуть } \\
\end{array}$ & $\begin{array}{l}\text { Не более 0,5 } \\
\text { Не более 0,1 } \\
\text { Не более 0,05 } \\
\text { Не более 0,03 }\end{array}$ & $\begin{array}{l}\text { Менее 0,1 } \\
\text { Менее 0,007 } \\
\text { Менее 0,005 } \\
\text { Менее 0,01 }\end{array}$ \\
\hline \multicolumn{3}{|c|}{ Антибиотики, мкг/г: } \\
\hline $\begin{array}{l}\text { Левомицетин } \\
\text { Тетрацик- } \\
\text { лин.гр. } \\
\text { Гризин } \\
\text { Бацитрацин } \\
\end{array}$ & $\begin{array}{l}\text { < } 0,01 \\
\text { Не доп. } \\
\text { Не доп. } \\
\text { Не доп. }\end{array}$ & $\begin{array}{l}\text { Менее 0,0075 } \\
\text { Не обнаружены } \\
\text { Не обнаружены } \\
\text { Не обнаружены }\end{array}$ \\
\hline \multicolumn{3}{|c|}{ Пестициды: } \\
\hline $\begin{array}{l}\text { Гексахлор - } \\
\text { циклогексан } \\
(\alpha, \beta, y-\text { изо- } \\
\text { меры) }\end{array}$ & 0,1 & Менее 0,05 \\
\hline $\begin{array}{l}\text { ДдТ и его } \\
\text { метаболиты }\end{array}$ & 0,1 & Менее 0,03 \\
\hline \multicolumn{3}{|c|}{ Нитрозамины } \\
\hline $\begin{array}{l}\text { Сумма НДМА } \\
\text { и НДЭА }\end{array}$ & 0,004 & Не обнаружены \\
\hline \multicolumn{3}{|c|}{ Радионуклиды, Бк/кг } \\
\hline $\begin{array}{l}\text { Цезий - } 137 \\
\text { Стронций - } 90\end{array}$ & $\begin{array}{l}40 \\
20\end{array}$ & $\begin{array}{l}\text { Менее } 5 \\
\text { Менее } 3\end{array}$ \\
\hline $\begin{array}{c}\text { Бенз(а)пи- } \\
\text { рен, мг/кг }\end{array}$ & Не более 0,001 & Не обнаружено \\
\hline
\end{tabular}

По результатам исследований показателей безопасности мясное изделие из оленины суджук «Праздничный» соответствовал требованиям СанПин 2.3.2.1078-01 и ТРTC 021/2011 «О безопасности пищевой продукции» $[11,12]$. 


\section{А. Т. ИНЕРБАЕВА}

Поскольку качество продукта питания представляет собой совокупность свойств, нами приведена описательная органолептическая характеристика сыровяленого колбасного изделия, которая представлена в таблице 4.

Таблица 4 - Органолептическая оценка суджука «Праздничный»

\begin{tabular}{|l|c|}
\hline Показатель & Характеристика \\
\hline Внешний вид & $\begin{array}{c}\text { Поверхность батона чистая, } \\
\text { сухая, без пятен, слипов, по- } \\
\text { вреждений оболочки, наплывов } \\
\text { фрарша }\end{array}$ \\
\hline Консистенция & Упругая \\
\hline $\begin{array}{l}\text { Вид на раз- } \\
\text { резе }\end{array}$ & $\begin{array}{c}\text { Фарш равномерно перемешан, } \\
\text { без серых пятен и пустот. До- } \\
\text { пускается мелкая пористость. } \\
\text { Фарш содержит: кусочки шпика } \\
\text { до 4 мм }\end{array}$ \\
\cline { 2 - 2 } & $\begin{array}{c}\text { кусочки оленины не более 4 мм } \\
\text { Вкус и запах } \\
\text { Вкус приятный, слегка острый, в } \\
\text { меру соленый, с выраженным } \\
\text { ароматом пряностей, копчения, } \\
\text { с запахом чеснока, без посто- } \\
\text { ронних запаха и привкуса }\end{array}$ \\
\hline $\begin{array}{l}\text { Форма и вяз- } \\
\text { ка батонов }\end{array}$ & $\begin{array}{c}\text { Батоны, связанные кольцами, } \\
\text { прессованные. Оболочки искус- } \\
\text { ств., черевы свиные, диамет- } \\
\text { ром 45 мм. }\end{array}$ \\
\hline
\end{tabular}

Установлено, что продукты из оленины не только не уступают, но и по некоторым показателям превосходят мясные изделия из говядины, в которых содержание белка на $2,9 \%$ меньше, чем в продуктах из мяса северного оленя [13, 14, 15].

Физико-химические показатели разработанных сыровяленых колбасных изделий представлены в таблице 5.

Таблица 5 - Физико-химические показатели сыровяленых колбасных изделий

\begin{tabular}{|c|c|}
\hline \multirow[t]{2}{*}{ Показатель } & Содержание \\
\hline & $\begin{array}{c}\text { суджук } \\
\text { «Праздничный» }\end{array}$ \\
\hline $\begin{array}{c}\text { Массовая доля белка, \%, не } \\
\text { менее }\end{array}$ & 19 \\
\hline $\begin{array}{l}\text { Массовая доля жира, \%, не } \\
\text { более }\end{array}$ & 7 \\
\hline $\begin{array}{l}\text { Массовая доля хлористого } \\
\text { натрия (поваренной соли), \%, } \\
\text { не более }\end{array}$ & 4,5 \\
\hline $\begin{array}{l}\text { Массовая доля влаги, \%, не } \\
\text { более }\end{array}$ & 25 \\
\hline $\begin{array}{l}\text { Массовая доля нитрита } \\
\text { натрия, \%, не более }\end{array}$ & 0,005 \\
\hline $\begin{array}{l}\text { Температура в толще продук- } \\
\text { та при выпуске с предприятия }\end{array}$ & от 0 до $8^{\circ} \mathrm{C}$ \\
\hline
\end{tabular}

В целом, энергетическая ценность 100 г сыровяленого колбасного изделия суджук «Праздничный» составила 139 ккал. Рекомендуемый срок годности сыровяленых колбасных изделий из оленины с момента окончания технологического процесса при температурах хранения: от 12 до $15^{\circ} \mathrm{C}$ и относительной влажности воздуха 75-78 \% 4 месяца, от -2 до $-4{ }^{\circ} \mathrm{C}-6$ месяцев, от -7 до $-9^{\circ} \mathrm{C}-9$ месяцев.

\section{ЗАКЛЮЧЕНИЕ}

Сотрудниками лаборатории технологии мяса и мясных продуктов проведена оценка безопасности мяса оленей, представлены стадии производства сыровяленого колбасного изделия из оленины суджука «Праздничный» и дана оценка его безопасности. Увеличение объема промышленной переработки этого вида нетрадиционного мясного сырья позволит рациональнее и эфффективнее осуществлять их реализацию.

Вся проведённая нами исследовательская работа позволит наиболее полно оценить перспективы использования оленины, что будет способствовать расширению ассортимента мясных изделий из нетрадиционного регионального сырья и повысить качество продуктов питания.

\section{СПИСОК ЛИТЕРАТУРЫ}

1. Распоряжение Правительства РФ от 29 июня 2016 г. № 1364-р «Об утверждении Стратегии повышения качества пищевой продукции в Российской Федерации до 2030 года» [Электронный ресурс]. - Режим доступа: http:// www.pravo.gov.ru. - Загл. с экрана.

2. Указ Президента РФ от 13 мая 2017 г. № 208. «О Стратегии экономической безопасности Российской Федерации на период до 2030 года». [Электронный ресурс]. - Режим доступа: http:// www.garant.ru> 71572608. - Загл. с экрана.

3. Нормы фризиологических потребностей в энергии и пищевых веществах для различных групп населения российской Федерации. Методические рекомендации (MP 2.3.1.2432- 08). - М. 2008. - 43c.

4. Основные проблемы переработки продуктов северного оленеводства и пути их решения / В. А. Углов, А. Т. Инербаева, Е. В. Бородай, С. Н. Перфильева // Международный журнал прикладных и фрундаментальных исследований. 2015. - № 9-1. - С. 31-34.

5. Колобов, С. В. Оленина - перспективное сырье для производства мясных продуктов высокого качества из отечественного сырья / С. В. Колобов, О. В. Орлова, И. А. Зачесова // Товаровед продовольственных товаров. - 2016. - № 3. ПОЛЗУНОВСКИЙ ВЕСТНИК № 32018 


\section{К ВОПРОСУ О БЕЗОПАСНОСТИ СЫРЬЯ И ПРОДУКТОВ ПЕРЕРАБОТКИ ИЗ ОЛЕНИНЫ}

C. 50-56.

6. Южаков, А. А. Возрастные изменения пищевой ценности мяса домашних северных оленей // Генетика и разведение животных. - 2018. № 2. - C. 129-134.

7. Мясная продуктивность диких северных оленей / О. И. Соломаха, Г. А. Полякова, Л. А. Мамеева, Л. А. Колпащиков // Мясная продуктивность северных оленей и пути ее повышения. Сиб. отд-ние ВАСХНИЛ. Новосибирск, 1982. C. 20-26.

8. ГОСТ 32227-2013 Олени для убоя. Оленина в тушах и полутушах. Технические условия. М.: Стандартинформ. - 2014. - 14 с.

9. ГОСТ 32243-2013 Мясо. Разделка оленины на отрубы. Технические условия. - М.: Стандартинформ. - 2014. - 12 с.

10. Санитарная микробиология / Н. В. Билетова, Р. П. Корнелаева, Л. Г. Кострикина [и др.] ; Под ред. С. Я. Любашенко. - М.: Пищевая пром сть, 1980. -352 с.

11. СанПиН 2.3.2.1078-01. Гигиенические требования безопасности и пищевой ценности пищевых продуктов. - Новосибирск. - 2002. 205 c.

12. ТРТС 021/2011 «О безопасности пищевой продукции». Утверждён Решением Комиссии Таможенного союза от 9 декабря 2011 г. № 880.
[Электронный ресурс]. - Режим доступа : http: // www. StandartGost.ru>gost/by_pkey/14293799243. Загл. с экрана.

13. Кудряшов, Л. С. Оценка мяса оленей и качества выработанных продуктов / Л. С. Кудряшов // Мясная индустрия. - 2011. - № 7. - С. 8-12.

14. Шорникова, Г. В. Пищевая и биологическая ценность рубленых полуфабрикатов из мяса северного оленя / Г. В. Шорникова, С. В. Колобов // Мясная индустрия. - 2008. - № 5. - С.28-31.

15. Колобов, С. В. Исследование пищевой и биологической ценности полуфабрикатов из оленины / С. В. Колобов // Товаровед продовольственных товаров. - 2018. - № 3. - С. 10-15.

Инербаева Айгуль Тойкеновна к.т.н., ведущий научный сотрудник Сибирского научно-исследовательского и технологического института переработки сельскохозяйственной продукции Федерального государственного бюджетного учреждения науки "Сибирского федерального научного центра агробиотехнологий российской академии наук», п. Краснообск, Новосибирской области, Россия, e-mail: atinerbaeva@yandex.ru. 